\title{
Use of Ayer's T piece circuit for monitored anaesthesia care for ERCP
}

\author{
S Bhargava ${ }^{I^{*}}, N$ Chakravarty $^{2}$, S Shende ${ }^{3}, R_{P}$ Patel $^{4}, R V$ Shidhay $e^{5}$ \\ Associate Professor ${ }^{1}$, Associate Professor ${ }^{2}$,Assistant Professor ${ }^{4}$, Professor $^{5}$, Department of \\ Anesthesiology and Critical Care, L.N.Medical College and J.K. Hospital, Kolar Road, Bhopal \\ 462042, India. Specialist ${ }^{3}$, Katju Hospital, Bhopal, India.
}

*Corresponding author: sumit_bhargava782000@yahoo.com

\begin{abstract}
Although moderate (conscious) sedation is intended during elective gastrointestinal endoscopy, unintended levels of deep sedation occur resulting in respiratory and cardiac compromise. We present here use of Ayre's T-piece circuit along with nasopharyngeal airway for Endoscopic Retrograde CholangioPancreatography (ERCP) procedure under sedation which negates all the above problems, ensuring safety of the patient.
\end{abstract}

Keywords: conscious sedation; endoscopic retrograde cholangiopancreatography; monitoring; Ayre's T-piece circuit

\section{Introduction}

Administration of sedation for a day care procedure like ERCP requires skill and vigilant monitoring. The anaesthesiologist's presence is mandatory in these cases. ${ }^{1}$ Level of sedation has to be adequate enough to allow the patient to tolerate the procedure comfortably without prolonging the time to discharge the patient. We present here use of Ayre's T-piece circuit along with nasopharyngeal airway for ERCP procedures under sedation which negates all the above problems, ensuring safety of the patient.

\section{Case report}

A 45 year female patient, diagnosed as a case of cholelithiasis with a stone in the common bile duct (CBD), leading to dilated CBD and intrahepatic biliary channels, was taken up for ERCP under sedation for extraction of CBD stone prior to a planned laparoscopic cholecystectomy. Apart from decreased haemoglobin $(\mathrm{Hb} 8.3 \mathrm{mg} \%)$ and increased serum bilirubin $(18 \mathrm{mg} \%)$ all other relevant investigations were within the accepted range. Standard fasting norms were followed and ranitidine $50 \mathrm{mg}$, ondansetron $4 \mathrm{mg}$, glycopyrrolate $0.2 \mathrm{mg}$ and midazolam $2 \mathrm{mg}$ was given intravenously. Patient was sedated with titrated doses of intravenous fentanyl up to a maximum of $100 \mu \mathrm{g}$, and intravenous propofol up to a maximum of $100 \mathrm{mg}$, following which i.v. infusion of propofol was given between 5$10 \mathrm{mg} / \mathrm{kg} / \mathrm{hr}$. We ensured that spontaneous respiration of the patient was maintained at all times. Once patient was adequately sedated, a size $7.0 \mathrm{~mm}$ ID nasal airway was inserted in the nasal cavity and attached to patient end of Ayres
T-piece circuit, with a 2 litre bag to the bag end.(Figure 1). The circuit was connected to theanaesthesia machine and oxygen flow given at $8-10 \mathrm{~L} /$ minute. Respiration was confirmed by observing bag movements and monitoring $\mathrm{SpO} 2$ and end tidal $\mathrm{CO}_{2}$. The procedure took 50 minutes for completion during which respiration and vital status was monitored and maintained. After the procedure, the nasal airway was removed and oral suction was done. Patient responded immediately to our commands and was discharged after 4 hours after satisfactorily fulfilling discharge criteria.

\section{Discussion}

A recent review of the gastrointestinal Clinical Outcomes Research Initiative (CORI) database found that cardiopulmonary events were the leading cause of unplanned events during gastrointestinal endoscopy. ${ }^{2,3}$ Patel et $\mathrm{al}^{4}$ reported that even when the targeted level of sedation was moderate, deep sedation occurred at least once in 85\% cases of ERCP. Thus ERCP was recognized as an independent risk factor of deep sedation and respiratory depression. Intubating the patient and giving general anaesthesia, is usually not preferred since this prolongs the procedure due to the time required for patient preparation, induction of anaesthesia, and tracheal intubation. Recovery may be prolonged due to deeper levels of anaesthesia needed for tolerance of the endotracheal tube defeating the concept of ERCP as a day care procedure. In addition, the cost per procedure will be higher. Presence of an endotracheal tube impedes the passage of the endoscope, which may necessitate the use of a smaller size endotracheal tube increasing the 
work of breathing with spontaneous respiration. The use of LMA has been tried but requires more care in the prone position because it can easily dislodge by manipulations done during the procedure and it does not secure the patient's airway in case of aspiration of gastric fluids. ${ }^{5}$ The device using Ayre's T-piece circuit along with nasopharyngeal airway obviated all these problems. Advantages of this device were:

1. Nasopharyngeal airway acted as a protective device and prevented airway loss in case level of sedation deepened.

2. Adequacy of respiration could be judged to some extent with the help of bag movements in a fully draped prone patient. Reservoir bag also helpedto increase the $\mathrm{FiO}_{2}$.

3. It was possible to administer nitrous oxide and volatile anaesthetic agents if required for some time during the procedure using high flow rates to defeat air dilution to some extent through this device.

4. Monitoring of end tidal carbon dioxide was possible.

5. Cheap and easily accessible.

We recognize the limitations of the device such as:

1. It is not possible to prevent air dilution completely though use of high flow rates can minimise it.

2. The end tidal carbon dioxide is not accurate though helps to give clue to it due to some air dilution through the open nostril and oral cavity.

3. Chances of aspiration exist but can be minimized by ensuring nil per oral status, premedicating with antacids, antiemetics and antisialogogues and constant suctioning through the endoscope.

Figure 1: Ayre's T-piece circuit along with nasopharyngeal airway in a prone patient for ERCP

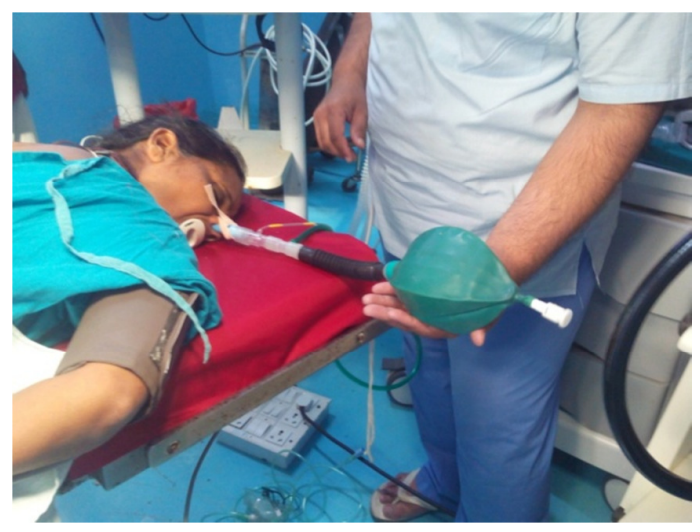

\section{References}

1. Chainaki IG, Manolaraki MM, Paspatis GA. Deep sedation for endoscopic retrograde cholangiopancreatography. World J GastrointestEndosc2011;3(2):34-39. http://dx.doi.org/10.4253/wjge.v3.i2.34 PMid:21403815 PMCid:PMC3055942

2. Vargo JJ, Zuccaro G Jr, Dumot JA, Conwell DL, Morrow JB, Shay SS. Automated graphic assessment of respiratory activity is superior to pulse oximetry and visual assessment for the detection of early respiratory depression during therapeutic upper endoscopy. GastrointestEndosc.2002;55:826-831. http://dx.doi.org/10.1067/mge.2002.124208 PMid:12024135

3. Robbertze R, Posner KL, Domino KB. Closed claims review of anaesthesia for procedures outside the operating room. Curr.Opin.Anaesthesiol 2006;19:436-442. http://dx.doi.org/10.1097/01.aco.0000236146.46 346.fe

PMid:16829728

4. Patel S, Vargo JJ, Khandwala F, Lopez R, Trolli P, Dumot JA, Conwell DL, Zuccaro G. Deep sedation occurs frequently during elective endoscopy with meperidine and midazolam. $\mathrm{Am}$ JGastroenterol.2005;100:2689-2695.

http://dx.doi.org/10.1111/j.15720241.2005.00320.x

PMid:16393221

5. Osborn IP, Cohen J, Soper RJ, Roth LA Laryngeal mask airway--a novel method of airway protection during ERCP: comparison with endotracheal intubation. GastrointestEndosc. 2002;56:122-128. http://dx.doi.org/10.1067/mge.2002.125546 PMid:12085051 